\section{Importance of digital spatial data in environmental education}

Wojciech Pokojski, Joanna Angiel, Paulina Pokojska

Summary:

DOI: $10.24131 / 3247.180105$

The article describes the importance of spatial data resources and GIS tools in environmental education. Data resources available at European and national level and possibilities of their use in education have been presented. Assessment of usefulness of these resources for environmental education objectives was made. Examples of use of spatial data in environmental education are presented. Key words: sustainable development, spatial data, GIS, environmental education

received: 17.07.2017; accepted: 17.08.2017; published: 13.12.2017

dr Wojciech Pokojski: Faculty of Geography and Regional Studies, University of Warsaw

dr hab. Joanna Angiel: Faculty of Geography and Regional Studies, University of Warsaw

dr Paulina Pokojska: Faculty of Geography and Regiona Studies, University of Warsaw

\section{Introduction}

Spatial data ${ }^{1}$ together with the tools for its visualization play a significant role in the environmental education. This issue is a point of interest to environmental stakeholders and GIS professionals. At the same time, however, it is also a point of interest to a number of social groups responsible for broadly sensed environmental education - both at the stage of school and academic education as well as the less formal education outside of school. The authors have adopted the following assumptions regarding the understanding of the term "environment" and its details, and consider the natural environment to be consisting of natural (both living and non-living) interrelated (systemically) and interacting components. Geographical environment is defined as a natural environment including some elements resulting from the human activity, i.e. anthropogenic elements (Jackowski, 2004).

The aim of this article is to identify and summarize public spatial data sources available at the European and national level and to discuss some opportunities for implementing them into the environmental education. Furthermore, answers were given to the following two questions: a) which public spatial data resources facilitate research and education projects related to ecology and sustainable development, and b) which geoportals should be used in environmental education and in implementing and presenting the ideas of sustainable development.

\section{The importance of spatial data in environmental education}

The great importance of spatial data in environmental education has been emphasized in reports, declara$\overline{1} \begin{aligned} & \text { Spatial data-referring to a particular location in the geographical } \\ & \text { space }\end{aligned}$ tions and publications concerning such education for several decades. In the United States, the postulates to introduce GIS tools and methods to natural, geographic and ecological education were presented almost 25 years ago (Palladino, Goodchild, 1993) and again 10 years later (Kerski, 2003). A comprehensive program to introduce GIS technologies into secondary education was established there in 2007 (NRC 2006). This coincided with the emergence of interactive maps, first geoportals and free of charge publication of some spatial data on the Internet. Up until 10 years ago the difficulty of accessing appropriate software (GIS) - and above all accessing spatial data - was continually emphasized. The rapid development of GIS software has triggered the demand for both raw data (data that require processing with appropriate software) and interactive maps and geoportals ${ }^{2}$. Since 2007, a lot has changed in terms of the availability of information technology and GIS tools. Open source software has spread and expanded, and some GIS features have been transferred to web applications and made available online as webGIS applications. The greatest progress has been made, however, in the availability of spatial information including spatial data. They are of great importance in environmental research and education, including education for sustainable development. With the use of GIS tools and applications, they allow for a comprehensive analysis of the correlation between human activities and the state of the natural environment and the changes taking place in it.

Using interactive maps with database access (Milson, Kerski, Demrici, 2012, Kerski, 2012) allows teachers and academic and school students to answer the following questions: 1) why are the studied objects located in a given place? 2) why and how do locations differ from each other? 3) how varied and variable is the peo-

2 Geoportal - a portal for searching and accessing spatial information and its visualization via the internet 
ple's interaction with the environment (living places) in the course of time and in the space? These aspects are closely linked to the need for providing education on sustainable development and to spatial data usage in doing so. The third one is, in fact, a question of the balance between economic, social, cultural and environmental concerns. Asking these questions and looking for answers is crucial to the education at the level of secondary, technical college and university education.

In the draft of a new geography curriculum for general secondary school and technical colleges, geographical information systems (GIS) were given a special role in learning about the world and detecting the complex problems of the geographic environment. The use of GIS in teaching geography has been included in the requirements, so after the implementation it will be biding to all geography teachers (Szkurłat et al., 2017).

The discussion on environmental education was initiated at the World Summit on Sustainable Development in Johannesburg in 2002, where the participants recommended adopting the Decade for Sustainable Development to be considered by the UN General Assembly. The implementation of the Summit in the area of geography was undertaken by the Commission on Geographical Education that operates within the framework of the International Geographical Union. The Lucerne Declaration on Geographical Education for Sustainable Development (2007) was adopted at the International Geographic Union Conference in Lucerne in 2007. It demanded to raise the importance of information and communication technologies (ICTs) including Geographic Information Systems (GIS) tools in environmental education ${ }^{3}$. At the same time, it brought attention to difficulties in accessing relevant data in this

3 The Importance of Information and Communication Technologies (ICT) in Education for Sustainable Development in Geography field, as well as issues related to the availability of hardware and software.

\section{Overview of public spatial data resources and their relevance in environmental education}

In the early years of GIS development, software distribution companies provided paying users with spatial data (usually it was data on administrative borders). The actions taken in 1990s by an American agency - The National Spatial Data Infrastructure (NSDI) - to "liberate spatial data" represented an important step in facilitating users' access to spatial data. As a result of these actions, the data that was mainly developed by American organizations and agencies such as USGS ${ }^{4}, \mathrm{NASA}^{5}$, NGIA $^{6}$, EROS $^{7}$ was made available to the entire world. However, raw data access requires their further transformation, processing, compilation and visualization using GIS tools as spatial data servers do not often have built-in webGIS (geoportal functions) tools to visualize online data (Pokojska, Pokojski 2015).

From the point of view of environmental education (including education for sustainable development), what is especially important is the access to spatial data with the possibility of visualization. In 2007, the European Union Directive INSPIRE establishing infrastructure for spatial information in the European Community was announced. Spatial data that was collected and developed under the aforementioned initiatives was summarized into three annexes covering thirty-four topics (Directive 2007). The following list contains topics that are closely related to spatial data:

- Attachment 1: coordinate reference systems, geographical grid systems, geographical names, ad-

4 USGS - United States Geological Survey

5 NASA - National Aeronautics and Space Administration

6 NGIA - National Geospatial-Intelligence Agency

7 EROS - Earth Resources Observation Systems ministrative units, addresses, cadastral parcels, transport networks, hydrography, protected sites

- Attachment 2: elevation, land cover, orthoimagery, geology

- Attachment 3: population distribution, land use, area management, natural risk zones, bio-geographical regions, habitats and biotopes, species distribution, energy resources, mineral resources

As a result of the INSPIRE Directive implementation and transposition into the EU Member States law, a number of projects has been launched, such as the INSPIRE Geoportal, the national geoportals of the EU countries, the thematic geoportals of environmental institutions. The INSPIRE Geoportal, operated by the European Commission, enables to search and access spatial information provided by European government institutions. This is an Internet application that allows you to view spatial data and search sets and services provided in accordance with the INSPIRE Directive ${ }^{8}$

The INSPIRE initiative is linked to the Joint Research Center, which is involved in its implementation. Its objective is, among others, to provide scientific and technical support in implementing and monitoring of EU policies. The center consists of seven scientific institutes, among them: The Institute for Environment and Sustainability (IES). The INSPIRE activities are also linked to the work of the EU Statistical Office EUROSTAT and the European Environment Agency (EEA). The objective of the EEA is to "provide sound, independent information on the environment for those involved in developing, adopting, implementing and evaluating environmental policy" (European Environment Agency). The Agency provides data to assist in the implementation of various projects regarding the environment and environmental education. It publishes reports on the environment and quality of life in Europe.

8 INSPIRE Geoportal: http://inspire-geoportal.ec.europa.eu 
Data and Maps (64 interactive maps) is an important collection of environmental information. It allows for the analysis of water quality (28 maps), air pollution (16 maps), land use changes (7 maps), urban development $\left(5\right.$ maps) etc. ${ }^{9}$ The data presented on the maps can be downloaded as text or database files. Data from these published reports as well as interactive maps can be used successfully in environmental education, especially in educational projects on phenomena occurrence analysis, their spatial diversity presentation or their dynamics. For example, maps containing PM2.5 and PM10, benzo(a)pyrene and lead spatial distribution from past years can be compiled and verified with maps on the smog phenomenon published in the Polish media in mid-2017.

Over the last two decades, a number of geographic environment initiatives that can be used in environmental education have been launched in the European Union. Currently, studies developed under the Copernicus project are of a great importance. It is a European monitoring system that is coordinated and managed by the European Commission. The data is obtained from Earth observation satellites (under the auspices of the European Space Agency) and in situ sensors such as earth, air and marine stations (under the auspices of the European Environment Agency). The Copernicus program includes global projects (vegetation, water and energy circulation) European projects (the abovedescribed CORINE Land Cover project, Image Mosaics project on high resolution satellite imagery and the European Settlement Map project showing settlement location and diversity) and local projects (Urban Atlas, Riparian zones and Natura 2000). Under the Corine Land Cover $^{10}$ (CLC) and Urban Atlas projects data on land use

9 http://www.eea.europa.eu/pl/publications\#c14=\&c12=\&c7=p1\&c $11=5 \& \mathrm{~b} \_$start $=0$

10 CORINE- Co-ordination of Information on Environment

patterns and their changes over time have been developed and published. CLC is a project that was launched in 1985 and aims to provide up-to-date information on land cover and land use across Europe (in a regular cycle and by demonstrating changes between cycles) Since 2000 , the project has been coordinated by the European Environment Agency. A coherent land cover legend was used to develop maps for the years 1990 2000, 2006 and 2012 (CLC1990, CLC2000, CLC2006 and CLC2012, respectively) and maps showing changes in land cover between those years. The data developed in the CLC project is widely used in studies on land use and land cover changes. The Urban Atlas project included preparing and publishing vector spatial data on land use within functional urban areas (FUA) in

\begin{tabular}{|l|l|l|}
\hline $\begin{array}{l}\text { Organisation/ } \\
\text { project }\end{array}$ & $\begin{array}{l}\text { Data server } \\
\text { address }\end{array}$ & Data type, usage \\
\hline $\begin{array}{l}\text { European } \\
\text { Environment } \\
\text { Agency }\end{array}$ & $\begin{array}{l}\text { http://www. } \\
\text { eea.europa. } \\
\text { eu/data-and- } \\
\text { maps }\end{array}$ & $\begin{array}{l}\text { Data, interactive maps, } \\
\text { indicators, publications on } \\
\text { the environment }\end{array}$ \\
\hline Copernicus & $\begin{array}{l}\text { http://land. } \\
\text { copernicus.eu } \\
(1990,2000,2006,2012), \text { high } \\
\text { resolution satellite imagery, } \\
\text { vector data from the Urban } \\
\text { Atlas, Natura 2000 and } \\
\text { Riparian zones projects }\end{array}$ \\
\hline $\begin{array}{l}\text { Geoportal } \\
\text { INSPIRE }\end{array}$ & $\begin{array}{l}\text { http://inspire- } \\
\text { geoportal. } \\
\text { ec.europa.eu/ }\end{array}$ & $\begin{array}{l}\text { tion, browsing data visualiza- } \\
\text { searching }\end{array}$ \\
\hline $\begin{array}{l}\text { Eurostat Por- } \\
\text { tal, Statistical } \\
\text { Atlas }\end{array}$ & $\begin{array}{l}\text { http:// } \\
\text { ec.europa.eu/ } \\
\text { eurostat } \\
\text { http:// } \\
\text { ec.europa.eu/ } \\
\text { eurostat/sta- } \\
\text { tistical-atlas/ } \\
\text { gis/viewer/ }\end{array}$ & $\begin{array}{l}\text { statistical data visualiza- } \\
\text { maps } \text { in the form of thematic }\end{array}$ \\
\hline
\end{tabular}

Table 1. Selected European spatial data sources

Source: own elaboration
Europe, updated for years 2006 and 2012. The Riparian zones project collected spatial data on land use in river valleys' floodplains occupied by riparian communities. This data was collected to monitor biodiversity in floodplain areas. Natura 2000 (N2K) project was designed to assess if the established Natura 2000 sites are properly protected.

Assembled data servers (projects) allow you to download raw data for further use in GIS software. The aforementioned projects' websites in the table (Table 1) offer mechanisms for viewing the processed resources in the form of interactive maps.

\section{Sharing data on the geographical environment in Poland}

The EU Member States are beholden to implement the INSPIRE Directive and introduce the national spatial information infrastructure. The Act on Spatial Information Infrastructure adopted on 4 March 2010 and implemented mainly within the framework of the Geoportal.gov.pl project (Pokojska, Pokojski 2013) is the legal instrument transposing the INSPIRE Directive into the Polish legal system. In this act (Act ... 2010), the Minister responsible for the environment, the Chief Inspectorate of Environmental Protection, the Chief Nature Conservator and others were obligated to perform activities related to providing spatial information on the environment. As a result, several portals have been created to provide access to the spatial information; they are listed in the table (Table 2).

Spatial data resources are available in Poland though the Geodesic and Cartographic Documentation Center (CODGiK) ${ }^{11}$ that publishes data on topography, alti-

11 CODGiK operates until 31 December 2017. From 2018 onward its tasks will be performed by the Head Office of Geodesy and Cartography. 


\begin{tabular}{|c|c|c|}
\hline Name of data source/geoportal & Address & Map resources \\
\hline Geoportal (national) & http://geoportal.gov.pl & $\begin{array}{l}\text { topographic and thematic maps with different scales, ortho- } \\
\text { photomaps, National Register of Boundaries, cadastral data, } \\
\text { shaded maps, General Geographic Database }\end{array}$ \\
\hline $\begin{array}{l}\text { Geodesic and Cartographic } \\
\text { Documentation Center }\end{array}$ & http://codgik.gov.pl/ & $\begin{array}{l}\text { collecting, conducting and sharing the central geodetic and } \\
\text { cartographic database, providing vector data from the BDOO } \\
\text { (General Geographic Objects Database), PRG (National Regis- } \\
\text { ter of Boundaries) and PRNG (National Register of Geographi- } \\
\text { cal Names) }\end{array}$ \\
\hline GIOŚ INSPIRE & http://inspire.gios.gov.pl/portal/ & $\begin{array}{l}\text { nature monitoring data regarding water, air, noise, electromag- } \\
\text { netic fields, ionizing radiation }\end{array}$ \\
\hline GDOŚ & http://geoserwis.gdos.gov.pl/mapy/ & $\begin{array}{l}\text { range of nature protection forms, animal crossings, sozological } \\
\text { map, hydrographic map }\end{array}$ \\
\hline RDOŚ Bydgoszcz & http://geoportal.rdos-bydgoszcz.pl/ & \multirow{2}{*}{$\begin{array}{l}\text { interactive maps: information layers on the values of the natu- } \\
\text { ral environment, forms of nature protection }\end{array}$} \\
\hline RDOŚ Katowice & $\begin{array}{l}\text { http://www.geoportal.rdos.kato- } \\
\text { wice.pl/geoportal/ }\end{array}$ & \\
\hline State Forests (forest map) & $\begin{array}{l}\text { http://www.lasy.gov.pl/nasze-lasy/ } \\
\text { mapa-lasow }\end{array}$ & $\begin{array}{l}\text { range of forest areas, Forest Promotion Complexes, forest fire } \\
\text { forecasts and periodic forest entry prohibitions }\end{array}$ \\
\hline $\begin{array}{l}\text { National Water Management } \\
\text { Authority }\end{array}$ & $\begin{array}{l}\text { http://geoportal.kzgw.gov.pl/gpt- } \\
\text { kzgw/catalog/main/home.page }\end{array}$ & river basins, water regions, homogenous water bodies \\
\hline Polish Geological Institute & $\begin{array}{l}\text { http://geoportal.pgi.gov.pl/portal/ } \\
\text { page/portal/PIGMainExtranet }\end{array}$ & $\begin{array}{l}\text { Central Database of Geological Data, access to downloadable } \\
\text { data in the shp format and in the WMS and WFS standards }\end{array}$ \\
\hline Tatra National Park & geoportaltatry.pl/ & \multirow{4}{*}{$\begin{array}{l}\text { interactive maps: ranges of national parks, educational trails, } \\
\text { terrain models, geology, hydrography, nature reserves }\end{array}$} \\
\hline Karkonosze National Park & www.gis.kpnmab.pl/ & \\
\hline Biebrza National Park & bpn.e-mapa.net/ & \\
\hline Bory Tucholskie National Park & gis.pnbt.com.pl/ & \\
\hline Geostatistics Portal & https://geo.stat.gov.pl/ & cartographic presentation of statistical data \\
\hline
\end{tabular}

Table 2. Selected Polish portals providing information on the geographical environment

Source: own elaboration

tude, terrain, and administrative borders. CODGIK is responsible for the national Geoportal, which provides multiple spatial data sets. The table (Table 2) also lists selected thematic geoportals prepared by various environmental protection institutions. Geoportal GIOŚ INSPIRE that was set up by the Chief Inspectorate of Environmental Protection provides access to nature monitoring data. In addition, the Geoportal led by the General Directorate for Environmental Protection (GDOŚ) provides access to data on forms of nature protection locations in Poland and to the Central Register of Nature Conservation Forms. There is also the National Water Management Authority geoportal, which provides access to hydrological data and Polish Geological Institute geoportal that contains geological data and groundwater resources.
The management of the regional directorates for environmental protection and national parks provides geographic information on the environment in their areas of activity on their geoportals. GUS (Central Statistical Office of Poland) has the Geostatistics Portal application - it is a modern solution that provides cartographical presentation of statistical results obtained in the censuses.

\section{Use of spatial data in environmental education - selected examples}

Downloadable spatial data that was made available through geoportals has been applied to projects in environmental education. In the sustainable development education projects (as part of geographic and biological education in school) the use of spatial data derived from various sources "allows to capture (...) human-nature interactions that are the essence of ecological education, but also to compare phenomena and their dynamics, sizes and ranges in different spatial scales" (Angiel et al., 2017), including areas of high educational potential such as the Vistula River Valley (Angiel, Angiel 2015, Angiel, 2010). The data obtained in the Urban Atlas project on the Vistula River valley is used during classes intended for postgraduate teachers at the University of Warsaw in the area of using the GIS techniques in teaching geography.

There is also an urbanization project in Spain which is great example of utilizing land use data. The project mentions that the results of land use change studies are of great importance for the principles of sustainable development (Gonzalez 2012). The GreenGo! Project is another example of an educational activity that includes data on land use change. The aim the project, which was carried out by GRID Warsaw was to raise awareness on the role of green infrastructure and the means for its 
sustainable development in rural areas. Furthermore education programs conducted in cross-border cooperation between Poland and Germany within the Education for Sustainable Development (German-Polish experience in Education for Sustainable Development) used data and GIS tools in projects implemented by young people concerning landscape transformations in some areas with strong anthropogenic and on the distribution of nature conservation areas.

\section{Summary}

The GIS technology enables integrating information from multiple sources into one system for spatial analysis, drawing conclusions and making decision. Initiatives related to the spatial data infrastructure development (e.g. INSPIRE, indirectly the development of GIS software including webGIS) have contributed to the high demand for spatial data. "Spatial data liberation" coincided with the rapid development of web applications. Geo-archives and geoportals were developed and free license computer applications were created. Spatial data (mostly available free of charge) which is used as a source of data by the creators of these applications has played a crucial role in these opportunities emergence. Both applications and spatial data can and should be used in the broad environmental education, including sustainable development education. They enable environmental education that accounts for special phenomena, show the correlation between of the components of the geographic environment and the form, intensity and extent of human activities.

The statement on the difficulty of accessing data and GIS tools presented at the International Geographic Union conference in 2007 - that was mentioned at the beginning of this article - has become obsolete in Poland and other EU countries within only ten years.

\section{References}

Angiel J, Pokojska P, Pokojski W (2017). Szanse, cele i możliwości edukacji ekologicznej nauczycieli $z$ wykorzystaniem mediów $i$ webGIS Edukacja ustawiczna dorosłych, no. 2, 52-62.

Angiel J, Angiel PJ (2015). Perception of River Value in Education for Sustainable Development (The Vistula River, Poland). Sustainable Development vol. 23, no. 3, John Wiley \&Sons; 188-201.

Angiel J (2010). Restoring the social value of rivers throught education the case of Vistula River in Warsaw. Miscellanea Geographica, vol. $14 ; 203-212$.

Dyrektywa 2007/2/WE Parlamentu Europejskiego i Rady z 14 marca 2007 r. ustanawiajaca infrastrukture informacji przestrzennej we Wspólnocie Europejskiej (INSPIRE) (Dz. Urz. UE L 108/2007)

Gonzalez R (2012). Geomedia for education in sustainable development in Spain. An experience in the framework of the aims of digital-earth.eu. European Journal of Geography vol. 3, no. 3; 44-56.

Jackowski A, red. (2004). Encyklopedia „Geografia”. Wyd. Zielona Sowa, Kraków; 531.

Kerski J (2003). The Implementation and Effectiveness of Geographic Information Systems Technology and Methods in Secondary Education. Journal of Geography vol. 106, no. 6, p.128-137.

Kerski J (2012). The role of GIS in Digital Earth education. International Journal of Digital Earth, vol. 4 no. 1; 326-346.

Milson A, Kerski J, Demrici A ( 2012). International perspectives on teaching and learning with GIS in secondary schools. Springer Publisher.

NCR 2006, National Research Council (2006). Learning to think spatially: GIS as a support system in the K-12 curriculum. Nationa Academy of Sciences.

Palladino SD, Goodchild MF (1993). A place for GIS in the secondary schools? Geo Info Systems, vol. 3 no. 4; 45-49.

Pokojska P, Pokojski W (2013). Geoportal krajowy ważnym źródtem informacji przestrzennej o środowisku geograficznym $w$ procesie edukacji. Edukacja Biologiczna i Środowiskowa, vol.1 945); 42-50.

Pokojska P, Pokojski W (2015). Web mapping Google application in environmental educations. Edukacja Biologiczna i Środowiskowa, vol. 1 (54); 51-56

Szkurłat E, Piotrowska I, Wieczorek T, Hibszer A, Rachwał T (2017) Nowa podstawa programowa z geografii dla liceum ogólnoksztatcacego oraz technikum. Geografia w szkole nr 3;26-31.

Ustawa $z 4$ marca 2010 r. o infrastrukturze informacji przestrzennej w Polsce (Dz. U. Nr 76, poz. 489 ze zm.)

\section{Netography}

Copernicus Land Monitoring Service: COPERNICUS: http://land. copernicus.eu/pan-european/corine-land-cover/clc-2012. Access 12.07.2017.

European Environment Agency: http://www.eea.europa.eu/pl/publi cations $\# c 14=\& c 12=\& c 7=p l \& c 11=5 \& b \_s t a r t=0$. Access 15.03.2017. Geoportal: http://www.geoportal.gov.pl/o-geoportalu/powiazaniageoportalu/powiazanie-z-inspire

GreenGo: http://greengo.gridw.pl/o-projekcie. Access 15.05.2017.

Niemiecko-polskie doświadczenia w Edukacji dla Zrównoważonego Rozwoju, ECO REG, Federal Ministry of Education and Research: http://www.rceeplock.nazwa.pl/files/rcee/mater_szkol/4_niemiecko_polskie.pdf. Access 15.04.2017.

INSPIRE Geoportal: http://inspire-geoportal.ec.europa.eu. Access 15.04.2017.

Geostatistics Portal: https://geo.stat.gov.pl/. Access 15.03.2017.

The Lucerne Declaration on Geographical Education for Sustainable Development of 2007: http://www.iau-hesd.net/sites/default/files/ documen ts/lucernedeclaration.pdf. Access 15.03.2017 